\title{
Class Explores Legal Aspects of Business Entities
}

\section{Tanya Marcum (Bradley University)}

\author{
KEYWORDS: Legal, Startups, Team Development, \\ student entrepreneurs, Student innovators.
}

\begin{abstract}
In 2011, I created a Law and the Entrepreneur course at Bradley University. It was the first course on its campus created for its new Turner School of Entrepreneurship. This course is exclusively for undergraduates, particularly juniors and seniors. It is designed for students across the campus interested in entrepreneurship, although it is housed in the Foster College of Business. The class focuses on the stages of a business -- from leaving your employer with your business idea to selling the business. Many guest speakers (both lawyers and entrepreneurs) inform the students of these stages and legal issues that entrepreneurs may encounter along the way.
\end{abstract}

\section{Classroom Exercise}

On the first day of my Law and Entrepreneurship course, the undergraduate students self-select small groups and brainstorm a problem that needs to be solved by a small business. They then discuss the creation of this small business within this small group. Throughout the entire semester, students apply legal concepts to this fictitious small business that their group has created.

Each exercise is worth 5 points. Students typically engage in 12 exercises throughout the semester, utilizing this fictitious small business. Throughout the semester the students will use this fictitious business to examine issues of taxation, contracts, founders agreements, additional investors, government involvement and the sale of their business, just to name a few of the exercises.

Among the first exercises (of many) that the students engage in is the choice of entity selection, which I describe below.

\section{Entity Selection}

When starting a new venture, choosing the right form of entity is important for entrepreneurs. Selection of the most appropriate business entity for a particular venture is an important and complex decision. Factors such as funding, taxation, management and control, liability, and ownership of the entity will vary depending on the form of business entity. The types of entity can be identified as follows:

- Sole proprietorship-This begins when a single entrepreneur starts a business. This "doing business as" entity is very easy to create and might only need a $\mathrm{d} / \mathrm{b} / \mathrm{a}$ form filed in the state where the business is operated. State and local licensing, permits, taxes and other compliance with regulations are required. This is not a separate legal entity, thus the sole proprietor is personally responsible for any liability of the business and must report the income of the business on the individual's tax returns.

- Partnership-This is technically formed anytime that two individuals or entities operate a business together. State statutes provide legal guidance over general and limited partnership, but a partnership agreement is recommended if deviation from the state partnership statute is desired. A partnership can own property, sue and be sued, and acquire debt. A partnership is a flow-through entity; the taxes go on the tax returns of the partners. Creditors of the partnership must first look for payment from the partnership, but if the assets are not there, individual partners can be held personally liable. A limited partnership must have at least one general partner and the limited partners cannot participate in the day-to-day activities of the partnership because they are really just investors who can personally lose only their investment in the partnership.

- Limited Liability Company-This entity has the same liability protections and tax benefits as an S Corporation, but which enjoys greater flexibility in terms of taxation and ownership. Owners are called members and should enter 
into a member agreement regarding the rights and responsibilities, rather than relying on the state statutes for limited liability companies. It is usually not formed by a business financed via venture capital funds, due to tax restrictions on the fund's tax-exempt partners; however, the LLC is an attractive entity for corporate investors and wealthy individuals.

- S Corporation-An entrepreneur must make a federal tax election to be an S corporation. Once the election is made, this entity provides the liability protection of a corporation but without its various levels of taxation. Taxation flows through to the owners. There are drawbacks to the $S$ corporation. It is limited to 100 shareholders, all of whom must be individuals--and some specific organizations--and cannot be foreign; and, it can only issue one class of stock.

- C Corporation-- Corporations provide the entrepreneur with personal liability protection and some tax benefits to the business. A corporation is a separate legal entity by law, and separate from its owners. A corporation incurs its own liabilities, including tax, contract, and product or service risks. As long as the corporation is properly managed as distinct from its shareholders, personal assets are not at risk. Ownership is easily transferred if a shareholder decides to exit the business. Corporations, however, face many formalities that are required by state statutes, including: establishment of a board of directors; an annual meeting; state filings; and an article of incorporation.

Corporations incur and must pay their own taxes. When shareholders receive dividends, those dividends are taxable to the shareholder.

- Other business entities-There are additional legal entities for businesses, such as the lowprofit limited liability company (known as a L3C), series limited liability company, limited liability partnership, limited liability limited partnership, joint venture, professional corporation, close corporation, non-profit corporation and $\mathrm{B}$ corporations.

\section{The Exercises}

Students complete two small group exercises on two different days. In the first exercise, students are asked to think about both a sole proprietorship and a partnership as possible entity forms for their small business. Students within each group discuss the following items:

1. List 5 things your entity should do or consider if you want to create a partnership?

2. Discuss why your entity cannot be a sole proprietorship.

3. If your business could be a sole proprietorship, what is the biggest reason why you would not select this entity?

4. What are 10 items that should be included in a partnership agreement?

5. An $\mathrm{S}$ corporation and a $\mathrm{C}$ corporation are creatures of what federal law?

Upon completion of their small group discussions, we then discuss these questions as an entire class.

The second exercise focuses on the limited liability company as the entity selection for the small groups and their business. Students focus on starting a small business in Illinois as a limited liability company. Students explore the Illinois Secretary of State's Cyber Drive website, which houses the necessary information. Once a student becomes familiar with a state's website for the its legal entities and forms, they should easily be able to navigate a similar website in any state. Students look at forms and informational guides in an attempt to learn what is necessary to file in order to create a limited liability company. Students must answer the following questions and present the results to the class:

1. List all required documents to create your business in Illinois.

2. List applicable fees and state the reason for the fees.

3. Calculate the total fees in Illinois to file this entity.

4. Select two states and compute the total fees required to create a limited liability company.

Again, the entire class discusses the findings of each group. Students explore series limited liability companies, foreign and domestic businesses, and the cost of creating a business in different states (which are very different).

\section{The Results}

As a result of these exercises, students gain a better knowledge on the decisions that must be made when selecting an entity for their start-up business. Selection 
of the most appropriate entity will lead to less personal liability for the entrepreneurs, better tax advantages, and the retention of management and control of the business decision making choices of their business.

\section{References}

152. M. Marcum \& E. S. Blair, Entrepreneurial decisions and legal issues in early venture stages: Advice that shouldn't be ignored, Business Horizons (2011)

(https://www.sciencedirect.com/science/article/p ii/S0007681310001527) 54, 143-152.

Additional Search Terms: entrepreneurship courses, teaching ideas, teaching resources, classroom ideas, entrepreneurship classes, business schools, business school classes, entrepreneurship students, professors 